\title{
PENGARUH PENERAPAN MODEL TPS (THINK PAIR SHARE) TERHADAP MINAT BELAJAR SISWA KELAS VII PADA MATA PELAJARAN BIOLOGI DI MTs NEGERI 1 PALEMBANG
}

\author{
Leny Marlina', Ummi Hiras Habisukan², Devy Arfika ${ }^{3 *}$ \\ ${ }^{1}$ Dosen Prodi Pendidikan PIAUD Fakultas Ilmu Tarbiyah dan Keguruan UIN Raden Fatah \\ Palembang \\ Jl. K. H. Zainal Abidin Fikri No. 1 A KM 3,5 Palembang 30124, Indonesia \\ ${ }^{2}$ Dosen Prodi Pendidikan Biologi Fakultas Ilmu Tarbiyah dan Keguruan UIN Raden Fatah \\ Palembang \\ Jl. K. H. Zainal Abidin Fikri No. 1 A KM 3,5 Palembang 30124, Indonesia \\ ${ }^{3}$ Mahasiswa Prodi Pendidikan Biologi Fakultas Ilmu Tarbiyah dan Keguruan UIN Raden \\ Fatah Palembang \\ Jl. K. H. Zainal Abidin Fikri No. 1 A KM 3,5 Palembang 30124, Indonesia \\ *Email:arfika_d@yahoo.com \\ Telp: +6282306183994
}

\begin{abstract}
TPS (think pair share) commonly called the methods of teaching and learning to think, pair, and share. This model gives students the opportunity to learn and work independently of each other. Models TPS (think pair share) has three steps, namely think, pair, and share. Each of the steps have a strategy that will allow the students to learn. The aim of the study was to determine the effect of Think Pair Share toward student's learning interest result on the biological at grade VII of MTs Negeri 1 Palembang for academic years on 2016/2017. The method was true experimental design with Posttest-Only Control Design type. The population in this research were all students of seventh grade of MTs Negeri 1 Palembang on 2016/2017 academic year. The sample was taken by using Cluster Random sampling. The sample was students as experiment class at grade VIIC and students as a control class at grade VIIB. The instrument of the study was the questionairre. The data analysis used t-test, and obtained ttest $=2,922$ of significant 0,05 that ttable $=1,667$, so it can be concluded that by $t$-test $>t$-table means that alternative hypothesis was accepted. Based on the results of this study concluded that the learning model TPS (think pair share) increase interest in studying biology on the topic of the interaction of living things and the environment in the seventh grade students of MTs Negeri 1 Palembang in Academic Year 2016/2017.
\end{abstract}

Key words: Student Learning Interest; Think Pair Share

\section{PENDAHULUAN}

Pendidikan adalah usaha sadar untuk mengembangkan potensi sumber daya manusia yang seutuhnya melalui kegiatan pengajaran. Ada dua konsep pendidikan yang berkaitan yaitu belajar dan pembelajaran. Konsep belajar berakar pada pihak peserta didik. Peserta didik secara tidak langsung harus aktif dalam mengembangkan potensinya untuk mewujudkan proses pembelajaran yang lebih baik supaya dapat bermanfaat bagi masyarakat, bangsa dan Negara. Hal ini sudah dijelaskan pada undang-undang Nomor 20 tahun 2003 tentang sistem pendidikan nasional yang menyatakan bahwa pendidikan adalah usaha sadar dan terencana untuk mewujudkan suasana belajar dan proses pembelajaran agar peserta didik secara aktif mengembangkan potensi dirinya untuk memiliki kekuatan 
spiritual keagamaan, pengendalian diri, kepribadian, kecerdasan, akhlak mulia, serta keterampilan yang diperlukan oleh dirinya, masyarakat, bangsa dan Negara (Kadir dkk, 2012).

Pendidikan harus dimiliki oleh semua peserta didik agar dapat mencapai kebahagiaan yang setinggi-tingginya dan dapat menghadapi tantangan pendidikan yang akan muncul. Hasbullah (2013) juga telah mengatakan bahwa pendidikan sebagai tuntunan hidup anak-anak, agar mereka mencapai keselamatan dan kebahagiaan yang setinggi-tingginya. Untuk itu, peserta didik terlebih dahulu untuk mengetahui tujuan dari pendidikan sehingga, dapat mengetahui betapa pentingnya suatu pendidikan itu sendiri. Tanpa tujuan pendidikan yang jelas, kehidupan masyarakat, bangsa dan Negara akan tidak terpenuhi sepenuhnya maka dari itu, untuk menwujudkan tujuan tersebut ialah dengan belajar.

Wahab (2012) telah mengatakan bahwa salah satu usaha yang dilakukan untuk mewujudkan tujuan pendidikan adalah dengan belajar. Belajar merupakan suatu usaha yang dilakukan dalam waktu yang panjang dalam rangka memperoleh ilmu pengetahuan dan keterampilan. Belajar dapat menjadikan anak-anak lebih baik karena ilmu yang dimilikinya. Belajar dipengaruhi oleh dua faktor yaitu faktor internal dan faktor esternal.

Faktor-faktor yang mempengaruhi belajar siswa yaitu faktor internal (faktor dari dalam siswa) terdiri dari kesehatan, bakat, minat, motivasi, dan cara belajar kemudian faktor eksternal (faktor dari luar diri siswa) terdiri dari keluarga, sekolah, masyarakat, dan lingkungan (Wahab, 2012). Salah satu faktor internal yang dapat mempengaruhi belajar siswa adalah minat. Minat merupakan faktor psikologis yang mempengaruhi prestasi belajar karena minat ialah kecenderungan dan kegairahan yang tinggi atau keinginan yang besar terhadap sesuatu (Khodijah, 2016).

Minat sangat berpengaruh terhadap hasil belajar siswa yang diperoleh siswa. Beberapa pendapat para ahli telah menjelaskan pengaruh minat belajar terhadap hasil belajar yang akan diperoleh siswa. Seperti yang dikatakan oleh Tu'u (2004) bahwa minat belajar yang tinggi akan memberi dampak yang baik bagi prestasi belajar siswa, juga Dayat (2009) mengatakan bahwa minat belajar terhadap suatu mata pelajaran akan menimbulkan keinginan untuk belajar sehingga dapat meningkatkan prestasi belajar siswa.

Minat belajar yang baik maupun yang rendah akan berpengaruh terhadap hasil belajar siswa itu sendiri. Hal ini terlihat saat pengamatan pra penelitian di MTs Negeri 1 Palembang dengan menyebar lembar angket minat untuk mengetahui sejauh mana minat belajar siswa itu sendiri. Berdasarkan hasil pengamatan pra penelitian yang dilakukan di MTs Negeri 1 Palembang dengan jumlah siswa sebanyak 294 siswa, didapatkan data awal hasil skala minat belajar siswa kelas VII yaitu terdapat $45,2 \%$ memiliki minat cukup, 26,2\% memiliki minat baik dan $28,6 \%$ memiliki minat yang sangat baik. Angka minat yang cukup lebih tinggi dari minat baik dan minat sangat baik. Hal ini selaras hasil kognitif belajar siswa. Berdasarkan data yang diperoleh mengenai hasil kognitif belajar siswa, didapatkan bahwa terdapat sebanyak $41,50 \%$ siswa yang tuntas dan $58,50 \%$ siswa yang tidak tuntas. Angka nilai yang tidak tuntas lebih tinggi dari nilai yang tuntas.

Hasil dari skala minat belajar dan hasil belajar siswa yang diperoleh masih dikategorikan rendah. Angka minat belajar siswa yang masih rendah juga terlihat dalam beberapa penelitian lain yaitu Ahn, Siegler, dan Chen (2016) di High School Science Taiwan dan Nugroho dan Edie (2015) di kelas XI SMAN 1 Kendal mengatakan bahwa siswa memiliki minat belajar yang masih rendah. Adapun yang mengakibatkan minat belajar yang rendah tersebut dikarenakan oleh beberapa faktor yang mempengaruhinya.

Faktor-faktor yang mempengaruhi minat dan hasil belajar yang rendah yaitu suasana belajar yang masih monoton, model pembelajaran yang kurang bervariasi juga materi yang masih sulit untuk dipahami oleh siswa itu sendiri. Hal ini terlihat saat observasi dengan guru mengenai pembelajaran Biologi di kelas. 
Pada kegiatan pembelajaran di kelas terlihat beberapa kendala dalam pelaksanaan pembelajaran biologi yaitu saat pembelajaran berlangsung masingmasing siswa masih kurang memahami materi yang diajarkan, suasana belajar tidak bersemangat sehingga angka minat belajar dan nilai hasil belajar siswa yang diperoleh masih belum tinggi. Hal Ini terjadi dikarenakan model pembelajaran yang diterapkan masih kurang bervariasi atau pembelajaran konvensional sehingga siswa mengalami hal tersebut

Menurut Matin (2013), mengatakan bahwa metode pembelajaran tradisional yang biasa diterapkan seperti ceramah, latihan, dan menghapalkan harus disempurnakan dengan metode yang lebih banyak memberikan inspirasi dan motivasi dalam belajar seperti belajar sambil berbuat, belajar untuk menemukan sendiri, dan belajar memecahkan masalah. Sukardi (2013) juga mengatakan bahwa model pembelajaran inovatif akan sangat membantu guru dalam meningkatkan efektivitas proses pembelajaran. Model pembelajaran yang inovatif salah satunya model TPS (think pair share). TPS (think pair share) biasa disebut metode belajar mengajar berpikir, berpasangan, dan berbagi. Model ini memberikan peserta didik kesempatan untuk belajar mandiri dan bekerja satu sama lain. Model think pair share memiliki tiga langkah yaitu think, pair, dan share. Setiap langkahlangkah memiliki strategi yang akan memberikan kemudahan peserta didik dalam belajar.

Adapun strategi dalam langkahlangkah think pair share yaitu, menurut Kurniasih (2015) mengatakan bahwa strategi think pair share dalam langkahlangkahnya memberikan kesempatan kepada peserta didik untuk berpikir mendalam (think), berdiskusi dengan pasangan (pair) sehingga keaktifan peserta didik akan meningkat sebab kelompok yang dibentuk tidak banyak, dan masingmasing peserta didik dapat dengan leluasa mengeluarkan pendapat mereka, dan menjelaskan kepada peserta didik secara keseluruhan (share). Sehingga dengan menggunakan model think pair share ini peserta didik aktif dapat belajar bersama dengan teman lainnya untuk berdiskusi dan menyampaikan hasil diskusi di depan pasangan kelompok lainnya. Strategi model think pair share ini memberikan arahan yang positif dalam pembelajaran sehingga akan memberikan pengaruh yang baik terhadap minat belajar siswa itu sendiri. Hal ini selaras dengan Mardodo, Budiyono dan Imam (2014), dalam penelitianya di SMP Negeri 1 Karangayar yang mengatakan bahwa pembelajaran dengan model think pair share berpengaruh baik terhadap minat belajar siswa.

Jurnal yang disusun oleh Bakri, dkk (2014), yang berjudul "Pengaruh Pembelajaran Kooperatif Tipe Think Pair Share pada Materi Sistem Pencernaan Manusia Terhadap Hasil Belajar Biologi Siswa Kelas VIII SMP Negeri 1 Kepenuhan Hulu Tahun Pembelajaran 2014/2015". Jurnal yang berisi tentang meningkatkan hasil belajar biologi siswa ditinjau dari aspek hasil kognitif belajar siswa dengan menggunakan model pembelajaran tipe think pair share (TPS).

Dalam penelitian tersebut yang diteliti adalah pengaruh model think pair share sama seperti penelitian yang akan dilakukan ini. Tetapi variabel terikatnya terhadap hasil belajar biologi sedangkan penelitian yang akan dilakukan ini menggunakan variabel terikat terhadap minat belajar biologi siswa.

\section{METODE PENELITIAN}

Penelitian ini akan dilaksanakan di MTs Negeri 1 Palembang. Berlangsung pada bulan Januari s.d selesai 2017. Sampel yang digunakan dalam penelitian ini adalah kelas VIIB dan VIIC. Kelas VIIB sebagai kelas eksperimen dan kelas VIIC sebagai kelas kontrol.

Jenis penelitian yang digunakan adalah penelitian deskriptif kuantitatif dengan metode eksperimen. Bentuk penelitian eksperimen yang digunakan ialah true experimental design (eksperimen yang betul-betul). Desain penelitian yang akan digunakan adalah posttest-only control design. Kelompok yang diberi perlakuan disebut kelompok eksperimen 
dan kelompok yang tidak diberi perlakuan disebut kelompok kontrol. Terdapat dua jenis variabel penelitian yaitu variabel bebas dan variabel terikat. Variabel bebas merupakan variabel yang mempengaruhi atau yang menjadi sebab perubahannya atau timbulnya variabel terikat. Variabel bebas dalam penelitian ini yaitu model pembelajaran TPS. Sedangkan variabel terikat ialah variabel yang dipengaruhi atau yang menjadi akibat, karena adanya variabel bebas. Variabel terikat dalam penelitian ini yaitu minat belajar siswa.

\section{Pelaksanaan Penelitian}

1. Melakukan observasi dan konsultasi dengan guru mata pelajaran Biologi.

2. Menghubungi sekolah yang akan dijadikan sebagai tempat penelitian

3. Menentukan subjek penelitian dan waktu penelitian

4. Membuat rencana pelaksanaan pembelajaran (RRP) dan angket

5. Memvalidasi angket kepada para pakar

6. Mempersiapkan materi dan media pembelajaran.

7. Pada pelaksanaan penelitian terdapat 3 kali pertemuan. Pelaksanaan penelitian pada kelas eksperimen menggunakan model pembelajaran TPS (think pair share). Sedangkan pelaksanaan penelitian pada kelas kontrol, model pembelajaran yang digunakan adalah metode ceramah. Setelah pertemuan ketiga selesai dilanjutkan membagikan angket dan tugas kepada masing-masing siswa.

8. Setelah mendapatkan data, selanjutnya dilakukan analisis data.Teknik analisis data yang digunakan pada penelitian ini adalah teknik analisis deskriptif dan inferensial.

9. Teknik analisis deskripstif digunakan untuk mendeskripsikan nilai rata-rata serta persentase dari hasil data skala minat belajar siswa, disertai dengan penyajian data dalam bentuk tabel dan grafik. Menurut Ismail (2014), adapun teknik penskoran untuk skala minat adalah sebagai berikut.

1) Mencari rentangan untuk masing-masing kategori dengan rumus :

Rentangan

$=\frac{\text { Skor Terting gi }- \text { Skor Terendah }}{\text { Banyak Kategori }}$

2) Membuat rentangan skor berdasarkan nilai rentangan.

3) Membuat kesimpulan nilai responden.

Selanjutnya, data skala minat belajar siswa di analisis dengan rumus persentase sebagai berikut.

$$
P=\frac{F}{N} \times 100 \%
$$

10. Teknik analisis inferensial dengan uji persyaratan analisis yang digunakan pada penelitian ini adalah uji normalitas dan homogenitas. Uji normalitas data yang dilakukan dengan menggunakan uji KolmogorovSmirnov. Uji homogenitas data yang dilakukan dengan menggunakan uji Levene Statictic. Uji normalitas dan homogenitas data dihitung dengan bantuan paket program SPSS 16.0.

11. Uji hipotesis (uji-t) menggunakan uji-t independent sample. Uji ini untuk mengetahui apakah hipotesis diterima atau ditolak, dilihat dari hasil uji $t$ yang didapatkan, diketahui bahwa nilai $t_{\text {hitung }}$ lebih besar dari nilai $t_{\text {tabel }}$ maka $\mathrm{H}_{\mathrm{a}}$ diterima dan $\mathrm{H}_{0}$ ditolak, artinya terdapat pengaruh model think pair share terhadap minat belajar siswa di MTs Negeri 1 Palembang. Untuk menghitung uji hipotesis ini menggunakan bantuan komputer program SPSS 16.0.

\section{HASIL DAN PEMBAHASAN}

\section{A. Hasil}

Dari hasil penelitian yang dilakukan mengenai pengaruh penerapan model TPS (Think Pair Share) terhadap minat belajar siswa kelas VII di MTsN 1 Palembang, 
maka diperoleh hasil penelitian berupa nilai persentase minat belajar pada kelas eskperimen dan kelas kontrol, kemudian diperoleh persentase dalam bentuk grafik, dapat dilihat pada tabel berikut:

Tabel 1. Perbandingan persentase minat belajar kelas kontrol dan kelas eksperimen

\begin{tabular}{ccccccc}
\hline \multirow{2}{*}{ No } & \multirow{2}{*}{ Skor } & \multirow{2}{*}{ Kriteria } & \multicolumn{2}{c}{ Frekuensi } & \multicolumn{2}{c}{ Persentase (\%) } \\
\cline { 3 - 6 } & & & Kontrol & Eksperimen & Kontrol & Eksperimen \\
\hline 1 & $81-100$ & Sangat Berminat & 12 & 19 & $28,57 \%$ & $45,24 \%$ \\
2 & $61-80$ & Berminat & 28 & 23 & $66,67 \%$ & $54,76 \%$ \\
3 & $41-60$ & Cukup Berminat & 2 & - & $4,76 \%$ & - \\
4 & $21-40$ & Kurang Berminat & - & - & - & - \\
5 & $0-20$ & Tidak Berminat & - & - & - & - \\
& & & $\mathbf{N = 4 2}$ & $\mathbf{N = 4 2}$ & $\mathbf{1 0 0 \%}$ & $\mathbf{1 0 0 \%}$ \\
\hline
\end{tabular}

Sumber: Data hasil penelitian (2017).

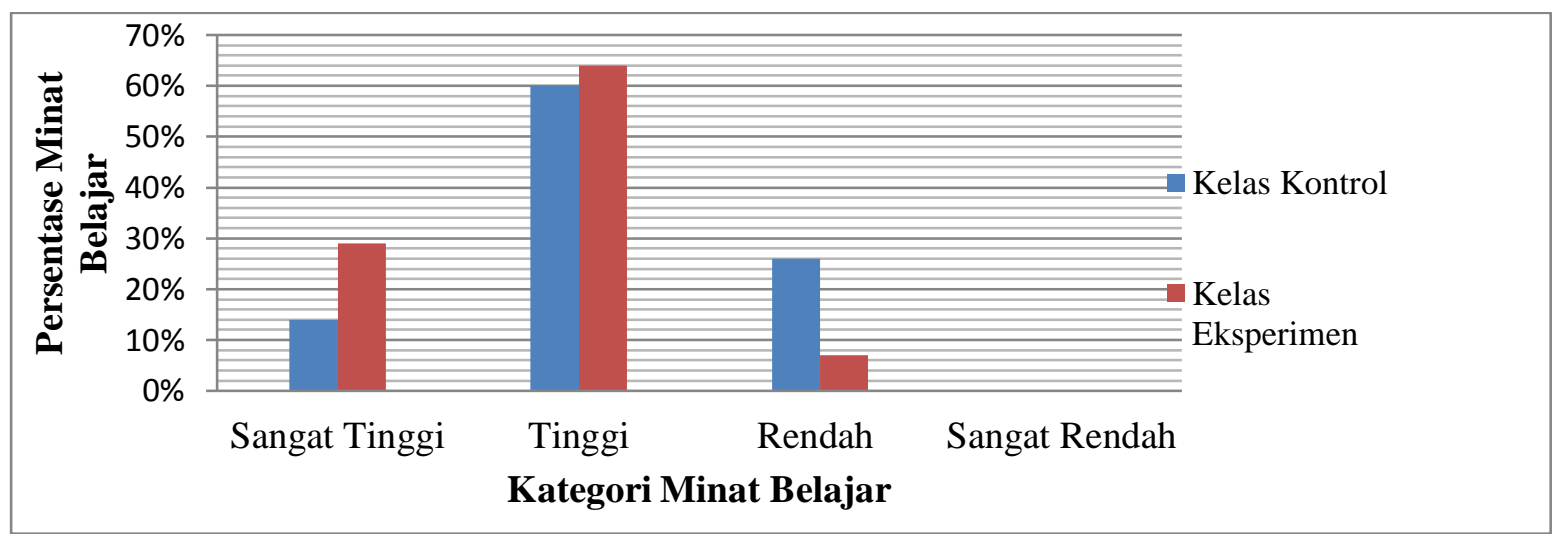

Gambar 1. Diagram perbandingan persentase minat belajar siswa kelas kontrol dan kelas eksperimen

Berdasarkan perhitungan secara deskriptif yang telah dilakukan pada skor skala minat belajar siswa, pada kriteria minat belajar "sangat tinggi", ada 6 siswa (14\%) dari kelas kontrol yang berada pada tingkat "sangat tinggi" sedangkan dari kelas eksperimen ada 12 (29\%) siswa. Lalu pada kriteria "tinggi" ada $25(60 \%)$ siswa dari kelas kontrol dan 27 (64\%) siswa dari kelas eksperimen dan terakhir pada kriteria "cukup", ada $11(26 \%)$ siswa dari kelas kontrol dan 3 (7\%) siswa dari kelas eksperimen yang menempatinya. Kelas eksperimen dan kelas kontrol jelas terlihat perbandingan. Jumlah siswa yang menempati kriteria sangat tinggi dan tinggi lebih banyak dibandingkan dengan kelas kontrol.

\begin{abstract}
Kemudian dilakukan uji analisis inferensial dengan jenis statistik parametrik, dimana uji ini dilakukan untuk mengetahui apakah ada pengaruh model think pair share terhadap minat belajar siswa. Pengaruh dilihat dengan cara menguji hasil data menggunakan uji-t, uji ini akan membuktikan apakah hipotesis yang telah dirumuskan dalam penelitian ini diterima atau ditolak. Teknik uji normalitas yang digunakan adalah teknik Kolmogorov-Smirnov sedangkan untuk uji homogenitas dengan teknik uji Levene Statistic. Kedua uji persyaratan analisis ini dilakukan dengan bantuan program SPSS 16.00. Berikut adalah hasil dari uji normalitas yang didapat dari output SPSS.
\end{abstract}


Tabel 2. Hasil uji normalitas dengan teknik uji Kolmogorov-Smirnov

\begin{tabular}{cccc}
\hline No & \multicolumn{1}{c}{ Variabel } & Signifikansi & Keterangan \\
\hline $\mathbf{1}$ & Minat Belajar Kelas Kontrol & $0,823>0,05$ & Data berdistribusi normal \\
& & & \\
$\mathbf{2}$ & Minat Belajar Kelas Eksperimen & $0,552>0,05$ & Data berdistribusi normal
\end{tabular}

Sumber: Data hasil penelitian (2017).

Berdasarkan hasil uji normalitas yang telah didapatkan, diketahui bahwa uji normalitas untuk kelas kontrol dan eksperimen yaitu sebesar 0,823 dan 0,552 $>0,05$, maka sesuai dengan dasar pengambilan keputusan dalam uji normalitas Kolmogorov-Smirnov, kedua data dinyatakan berdistribusi normal.

Setelah data dinyatakan normal, dilanjutkan dengan uji homogenitas. Uji ini dilakukan untuk mengetahui apakah sampel yang digunkan dalam penelitian merupakan sampel yang homogen. Berdasarkan perhitungan uji homogenitas yang telah dilakukan, maka hasilnya adalah sebagai berikut:

\section{Tabel 3. Hasil uji homogenitas dengan teknik Levene Statistic Test of Homogeneity of Variances}

\begin{tabular}{cccc}
\hline Minat & & & \\
\hline Levene Statistic & df1 & df 2 & Sig. \\
\hline 1.652 & 1 & 82 & .202 \\
\hline
\end{tabular}

Sumber: Data hasil penelitian (2017).

Berdasarkan hasil uji homogenitas yang telah didapatkan, diketahui bahwa nilai signifikansi uji homogenitas untuk kelas kontrol dan eksperimen yaitu sebesar 0,202 > 0,05, maka sesuai dengan dasar pengambilan keputusan dalam uji homogenitas Levene Statictic, data dinyatakan memiliki varian yang sama atau homogen. Setelah data dari uji normalitas dinyatakan nomal dan uji homogenitas dinyatakan homogen, maka dilanjutkan dengan uji hipotesis (uji-t). Berikut hasil uji hipotesis (uji-t) yang diperoleh

Tabel 4. Hasil uji hipotesis dengan Uji t

\begin{tabular}{llllll}
\hline \multicolumn{1}{c}{ Variabel } & Mean & $\mathbf{t}_{\text {hitung }}$ & $\mathbf{t}_{\text {tabel }}$ & Sig. & \multicolumn{1}{c}{ Kesimpulan } \\
\hline Minat Belajar Kelas Eksperimen & 80,26 & & & & \\
& & & & & $\mathrm{H}_{\mathrm{a}}$ diterima \\
Minat Belajar Kelas Kontrol & 75,45 & & & & $\mathrm{H}_{0}$ ditolak
\end{tabular}

\section{Sumber: Data hasil penelitian (2017).}

Untuk mengetahui apakah hipotesis diterima atau ditolak, dilihat dari hasil uji t yang didapatkan, diketahui bahwa nilai $t_{\text {hitung sebesar 2,922, berdasarkan tabel }}$ distribusi $t$, nilai $t_{\text {tabel }}$ untuk $\mathrm{df}=82$ adalah sebesar 1,667, dan nilai signifikansi 0,004
$<0,05$. Dengan nilai $t_{\text {hitung }}>t_{\text {tabel, maka }}$ sesuai dengan dasar pengambilan keputusan dalam uji-t independent sample dapat disimpulkan bahwa $\mathrm{H}_{\mathrm{a}}$ diterima dan $\mathrm{H}_{0}$ ditolak, artinya terdapat pengaruh 
model think pair share terhadap minat belajar siswa di MTs Negeri 1 Palembang.

Selain itu, dari hasil uji $\mathrm{t}$ di atas, diketahui bahwa mean (nilai rata-rata) minat belajar di kelas eksperimen lebih besar daripada di kelas kontrol dengan masing-masing mean yaitu 79,78 dan 75,88 jadi dapat diketahui bahwa ada pengaruh yang positif dari penggunaan model think pair share terhadap minat belajar pada kelas eksperimen.

Tabel 5. Hasil pencapaian indikator minat belajar siswa

\begin{tabular}{cccccc}
\hline \multirow{2}{*}{ No } & \multirow{2}{*}{ Indikator } & \multicolumn{2}{c}{ Kelas Eksperimen } & Kelas Kontrol \\
\cline { 3 - 5 } & & Pencapaian & Kategori & Pencapaian & Kategori \\
\hline 1 & Perasaan senang & $80,00 \%$ & Tinggi & $75,04 \%$ & Tinggi \\
2 & Perasaan Tertarik & $75,23 \%$ & Tinggi & $75,23 \%$ & Tinggi \\
3 & Perhatian & $79,14 \%$ & Tinggi & $74,28 \%$ & Tinggi \\
4 & Partisipasi & $84,76 \%$ & Sangat & $78,95 \%$ & Tinggi \\
& & & Tinggi & Tinggi \\
\hline
\end{tabular}

Sumber: Data hasil penelitian (2017).

\section{Pembahasan}

\section{Pelaksanaan model Think Pair Share terhadap Minat belajar siswa di MTs N 1 Palembang}

Penelitian dilaksanakan di dua kelas. Kelas pertama adalah kelas VII.B untuk kelas eksperimen diberi perlakuan model TPS. Kelas kedua adalah kelas VII.C untuk kelas kontrol diberi perlakuan metode ceramah. Penelitian dilakukan sebanyak 3 kali pertemuan untuk masing-masing setiap kelas.

Model yang akan diterapkan saat pembelajaran di kelas eksperimen yaitu TPS. Model ini memiliki 3 langkah yaitu think, pair dan share. Peneliti membimbing siswa untuk menemukan kata penting di dalam teks bacaaan tentang ekosistem, karena beberapa siswa masih belum mengetahui arti dari kata-kata Latin di buku bacaan Biologi yang menjadi pegangan siswa untuk belajar. Pada tahap think, siswa untuk berfikir sendiri (think) dalam mengajukan suatu pertanyaan terkait materi ekosistem agar siswa sudah mulai paham sebelum melanjutkan materi dan tahap belajar berikutnya (Lampiran 17, Gambar c). Selanjutnya, tahap berpasangan (pair), siswa maju ke depan kelas untuk berpasangan dengan temannya. Tahap pair ini, setiap pasangan kelompok secara bersama-sama mencari komponen ekosistem yang ditemukan dan menuliskan hasil temuan mereka di lembar kerja siswa, lalu siswa kembali ke kelas. Siswa berdiskusi dengan tenang, masing-masing siswa mencurahkan dan menyatukan ideide nya (Lampiran 17, Gambar e).

Terakhir, tahap berbagi (share), siswa antusias ikut berpartisipasi dalam bertanya saat diminta untuk menyajikan hasil diskusi mereka di depan kelas (Lampiran 17, Gambar h). Guru meminta siswa untuk bertanya maupun menjawab pertanyaan dari kelompok yang lain. Siswa yang aktif dalam bertanya dan menjawab akan diberikan reward berupa poin plus sehingga siswa lebih bersemangat dalam tanya jawab. Pada tahap berbagi jawaban di depan kelas, tiap kelompok senang dan ikut berpartisipasi dalam menyajikan hasil diskusinya di depan kelas. Setelah pembelajaran selesai sesuai dengan langkah-langkah pelaksanaan pembelajaran yang telah direncanakan, interaksi antar siswa terlihat sehingga pembelajaran menjadi aktif dan tidak monoton.

Pada saat proses pembelajaran, siswa menunjukkan rasa ingin tahu dengan 
bertanya apa itu think pair share, dikarenakan selama ini mereka belum mempelajari model tersebut yang diterapkan saat pembelajaran di kelas. Siswa penasaran dengan model yang disingkat TPS tersebut. Siswa memerhatikan dengan saksama saat peneliti menjelaskan tentang apa yang mereka harus lakukan dalam pembelajaran dengan model think pair share ini, rasa ingin tahu siswa yang muncul juga dapat dilihat dari mereka yang membaca lembar kerja siswa. Setelah semua kegiatan pembelajaran pada pertemuan ketiga terselesaikan, siswa diminta untuk memberikan jawaban pada skala minat belajar siswa (Lampiran 17, Gambar h).

Kemudian, pada kelas kontrol di pertemuan pertama, setelah kegiatan awal pembelajaran dilaksanakan (Lampiran 17, Gambar a), dilanjutkan dengan kegiatan inti yaitu pembelajaran dengan metode ceramah. Peneliti memberikan penjelasan materi tentang interaksi makhluk hidup dan lingkungannya. Siswa lalu memerhatikan penjelasan materi yang disampaikan peneliti. Pada akhir pembelajaran, masingmasing siswa menuliskan kesimpulan dari pembelajaran tadi (Lampiran 17, Gambar g). Kegiatan pembelajaran terus berlanjut sesuai dengan langkah-langkah pelaksanaan pembelajaran yang telah direncanakan, begitu seterusnya hingga proses pembelajaran selesai. Setelah semua kegiatan pembelajaran terselesaikan, siswa diminta memberikan jawaban pada lembar skala minat belajar siswa (Lampiran 17, Gambar h).

Setelah melaksanakan penelitian maka diperoleh data hasil skor rata-rata minat belajar siswa yang diajarkan dengan model think pair share lebih besar dibandingkan dengan skor rata-rata minat belajar siswa yang diajarkan dengan metode ceramah. Dimana dalam proses pembelajaran dengan model think pair share, siswa dibimbing dan diarahkan untuk belajar secara aktif, saling berinteraksi satu sama lain dan menghargai waktu untuk belajar bersama dengan teman sehingga siswa memiliki rasa senang, tertarik, perhatian, dan keinginan partisipasi sesuai dengan indikator-indikator minat belajar.
Berdasarkan perhitungan secara deskriptif yang telah dilakukan pada skor skala minat belajar siswa, pada kriteria minat belajar "sangat tinggi", ada 6 siswa (14\%) dari kelas kontrol yang berada pada tingkat "sangat tinggi" sedangkan dari kelas eksperimen ada 12 (29\%) siswa. Lalu pada kriteria "tinggi" ada $25(60 \%)$ siswa dari kelas kontrol dan 27 (64\%) siswa dari kelas eksperimen dan terakhir pada kriteria "cukup", ada $11(26 \%)$ siswa dari kelas kontrol dan 3 (7\%) siswa dari kelas eksperimen yang menempatinya. Kelas eksperimen dan kelas kontrol jelas terlihat perbandingan. Jumlah siswa yang menempati kriteria sangat tinggi dan tinggi lebih banyak dibandingkan dengan kelas kontrol. Perbandingan antara keduanya pun bisa dilihat pada tabel 7 .

Kemudian, berdasarkan perhitungan pencapaian indikator minat belajar siswa, pada indikator perasaan senang "sangat baik" $(80,00 \%)$, indikator perasaan tertarik "baik" $(75,23 \%)$, indikator perhatian "baik" (79,14\%) dan indikator partisipasi "sangat baik" (84,76\%). Jumlah total pencapian indikator minat belajar pada kelas eksperimen adalah "sangat baik" (80,78\%). Sedangkan perhitungan pencapaian indikator minat belajar siswa di kelas kontrol, pada indikator perasaan senang "baik" $(75,04 \%)$, indikator perasaan tertarik "baik" (75,23\%), indikator perhatian "baik" $(74,28 \%)$ dan indikator partisipasi "baik" (78,95\%). Jumlah total pencapian indikator minat belajar pada kelas eksperimen adalah "baik" (75,88\%). Pebandingan antara keduanya pun bisa dilihat pada lampiran 14.

Dari belajar secara aktif telah dipaparkan oleh Slameto (2015) bahwa belajar secara aktif dengan mempergunakan banyak variasi metode pada waktu mengajar akan mengakibatkan penyajian bahan pelajaran lebih menarik perhatian siswa, mudah diterima siswa, dan kelas menjadi hidup. Metode penyajian yang selalu sama akan membosankan siswa. Kegiatan yang diminati siswa, diperhatikan terus-menerus yang disertai dengan rasa senang dan dari situ siswa akan merasakan kepuasan dalam belajar. 
Minat besar pengaruhnya terhadap belajar, karena bila model pembelajaran dan bahan pelajaran kurang diminati siswa, tidak ada daya tarik baginya, maka timbullah kebosanan, sehingga ia kurang bersemangat dalam belajar. Oleh sebab itu model think pair share bisa digunakan sebagai salah satu model pembelajaran yang dapat membuat siswa lebih aktif dan dapat mempengaruhi minat belajar siswa tersebut. Ismail (2014), belajar dengan minat akan mendorong siswa belajar lebih baik daripada belajar tanpa minat. Hal ini terlihat dari perbedaan jumlah siswa yang menempati kriteria minat belajar "sangat tinggi", dan "tinggi" antara kelas kontrol dan kelas eksperimen yang telah dijelaskan di atas.

Kemudian berdasarkan tabel 11 kelas eksperimen memperoleh skor rata-rata minat belajar yang lebih tinggi daripada kelass kontrol, yaitu 80,78 untuk kelas eksperimen dan 75,88 untuk kelas kontrol. Selanjutnya, dari hasil analisis uji hipotesis, dapat dikatakan penggunaan model think pair share dalam pembelajaran Biologi dapat mempengaruhi minat belajar siswa. Hal ini bisa dilihat dari hasil uji-t yang telah dilakukan, dimana $t_{\text {hitung }}=2,922>t_{\text {tabel }}=1,667$ dengan $\alpha=5 \%$, maka hipotesis alternatif yang berbunyi ada pengaruh model think pair share terhadap minat belajar siswa pada mata pelajaran Biologi di MTs Negeri 1 Palembang diterima.

Seperti yang dituliskan pada latar belakang, bahwa permasalahan kurangnya minat belajar siswa dalam pembelajaran Biologi dapat diatasi dengan penerapan pembelajaran aktif (active learning). Metode pembelajaran tradisional harus disempurnakan dengan metode yang lebih banyak memberikan inspirasi dan motivasi dalam belajar (Matin, 2013). Metode pembelajaran inovatif akan sangat membantu guru dalam meningkatkan efektivitas proses pembelajaran (Sukardi, 2013).

Model think pair share merupakan salah satu dari model pembelajaran yang lain yang sesuai untuk mempengaruhi minat belajar siswa. Menurut penelitian Danik Nurjanah (2010), yang berjudul
"Penerapan Pembelajaran Kooperatif Think Pair Share untuk Meningkatkan Minat Belajar Biologi Siswa Kelas X-3 Negeri Mojolaban Tahun Ajaran 2010/2011" menjelaskan bahwa TPS bisa digunakan sebagai pembelajaran kooperatif dengan siswa yang bekerja dan berinteraksi satu sama lain dalam belajar. Hal ini menunjukkan bahwa hasil belajarnya meningkat dan aktivitas siswa bekerja sama dalam kelompok. Siswa dan guru menunjukkan bahwa terdapat sikap positif dalam pembelajaran ini.

Think pair share merupakan model pembelajaran yang bisa membuat siswa aktif dalam belajar. Siswa kelas VII.B dan VII.C sebenarnya sudah baik dalam belajarnya terlihat dari pembelajaran pertemuan pertama sampai pertemuan ketiga, dimana siswa aktif dan antusias dalam bertanya jawab apalagi saat memberikan kesimpulan di depan kelas. Saat pembelajaran, kondisi belajar siswa juga tenang dan kondusif sehingga proses pembelajaran berjalan dengan cukup baik dan lancar.

Dari semua uraian yang telah disampaikan, telah diketahui bahwa model think pair share memberikan pengaruh yang positif daripada penggunaan metode diskusi dan ceramah, karena pada pelaksanaan model think pair share, siswa dituntut untuk berinteraksi antar sesamanya, berdiskusi, saling bertukar ide dan menyatukan ide-ide mereka dan berbagi jawaban di depan siswa lainnya. Aktivitas-aktivitas belajar di kelas membuat siswa dilibatkan aktif sehingga dapat berpengaruh positif dalam meningkatkan minat belajar siswa karena mampu meningkatkan aktivitas-aktivitas belajar siswa dalam mengikuti pelajaran. Metode ceramah yang sering guru gunakan juga sudah cukup baik, namun jika digunakan secara terus-menerus tentu akan membuat proses pembelajaran menjadi membosankan dan monoton yang akan berpengaruh pada minat belajar siswa. Sehingga alangkah baiknya jika guru menggunakan model pembelajaran yang lebih beragam, yaitu salah satunya model think pair share. 


\section{Hubungan model Think Pair Share terhadap peningkatan minat belajar siswa}

Berdasarkan hasil pada nilai posttest berupa angket skala minat belajar siswa dan uji hipotesis menggunakan uji t-test, menunjukkan bahwa terdapat pengaruh model think pair share terhadap minat belajar siswa. Selain itu, minat belajar siswa terlihat sesuai dengan indikator minat belajar siswa sebagai berikut:

a) Perasaan Senang

Berdasarkan lampiran 13, diketahui bahwa hasil skala minat belajar siswa dengan indikator perasaan senang yaitu pada kelas eksperimen memiliki pencapaian $80,00 \%$ dengan kategori sangat tinggi, sedangkan pada kelas kontrol memiliki pencapaian $75,04 \%$ dengan kategori tinggi. Hal ini selaras dengan penelitian yang telah dilakukan Evi (2014), berdasarkan hasil penelitiannya bahwa hasil skala minat belajar siswa indikator perasaan senang adalah cukup baik dengan rata-rata jawaban sebesar 3,82. Siswa menjadi bersemangat dalam mengikuti pembelajaran dan senang dengan teman pasangan diskusi kelompok mereka setelah diterapkan model pembelajaran think pair share terhadap minat belajar.

Pada kelas eksperimen dengan indikator perasaan senang tercermin dalam sintak model think pair share sebagai berikut:

a. Tahap berpasangan

Pada tahap berpasangan, siswa senang berpasangan dengan pasangan kelompoknya. Masingmasing pasangan kelompok berkerja sama dalam diskusi kelompok. Diskusi kelompok terlihat efektif dan menyenangkan karena kelompok yang dibentuk tidak banyak. Setiap pasangan berinteraksi satu sama lain untuk menyalurkan ide dan menyatukan ide-ide mereka. Setelah selesai berdiskusi, setiap pasangan dipersilahkan maju ke depan untuk memberikan hasil dari diskusi nya.

b. Tahap berbagi jawaban hasil diskusi

Pada tahap berbagi jawaban hasil diskusi, siswa secara bergiliran maju ke depan kelas untuk menceritakan hasil diskusinya. Setiap pasangan kelompok terlihat antusias dan senang saat berbagi jawaban hasil diskusi tentang ekosistem di depan pasangan kelompok lainnya.

Pada kelas kontrol menggunakan metode ceramah, suasana pembelajaran di kelas kontrol terlihat membosankan dan antusias siswa masih rendah pada saat siswa diminta untuk menceritakan gambaran ekosistem sebidang sawah.

b) Perasaan tertarik

Berdasarkan lampiran 13, diketahui bahwa hasil skala minat belajar siswa dengan indikator perasaan tertarik yaitu pada kelas eksperimen memiliki pencapaian $75,23 \%$ dengan kategori tinggi, sedangkan pada kelas kontrol memiliki pencapaian $75,23 \%$ dengan kategori tinggi. Kelas eksperimen dan kelas kontrol memiliki skor yang sama. Hal ini selaras dengan penelitian yang telah dilakukan Evi (2014), berdasarkan hasil penelitiannya bahwa hasil skala minat belajar siswa indikator perasaan tertarik adalah cukup baik dengan ratarata jawaban sebesar 3,72. Selain itu sama halnya dengan penelitian Rauf (2013), nilai persentase dari indikator perasaan tertarik yaitu sangat baik dengan rata-rata $100 \%$. Siswa terpikat atau tertarik terhadap materi yang diajarkan dan ingin untuk melestarikan pengalaman tersebut. Dengan demikian siswa merasa lebih puas dengan aktivitas belajarnya yang menarik hatinya setelah diterapkan model pembelajaran think pair share terhadap minat belajar.

Pada kelas eksperimen dengan indikator perasaan tertarik tercermin dalam sintak model think pair share sebagai berikut:

a. Tahap berpasangan

Pada tahap berpasangan, siswa berpasangan dengan teman sebangkunya. Siswa tertarik dengan pasangannya dalam berkerja sama untuk mendiskusikan tentang materi yang dipelajari. Diskusi kelompok ini membuat siswa merasa lebih puas karena aktivitas 
dari cara belajar tersebut dapat menarik hatinya.

b. Tahap berbagi jawaban hasil diskusi

Pada tahap berbagi (share), siswa menyampaikan hasil jawaban diskusi nya di depan kelompok yang lain. Kelompok yang lain tertarik untuk mendengarkan jawaban hasil diskusi mereka. Jawaban hasil diskusi yang telah banyak di sampaikan di depan kelas sangat bermanfaat sehingga menarik hati untuk memperoleh wawasan dan ilmu baru.

Pada kelas kontrol menggunakan metode ceramah, suasana pembelajaran di kelas kontrol terlihat kurang bersemangat saat siswa diminta untuk memberikan kesimpulan di akhir pembelajaran.

c) Perhatian

Berdasarkan lampiran 13, diketahui bahwa hasil skala minat belajar siswa dengan indikator perhatian yaitu pada kelas eksperimen memiliki pencapaian $79,14 \%$ dengan kategori sangat tinggi, sedangkan pada kelas kontrol memiliki pencapaian $74,28 \%$ dengan kategori tinggi. Hal ini selaras dengan penelitian yang telah dilakukan Evi (2014), berdasarkan hasil penelitiannya bahwa hasil skala minat belajar siswa indikator perhatian adalah cukup baik dengan rata-rata jawaban sebesar 3,72. Selain itu sama halnya dengan penelitian Guratno dan Nurul (2014), nilai persentase dari indikator perhatian yaitu baik dengan rata-rata $75 \%$. Siswa dalam mengikuti pembelajaran telah mengetahui tujuan dan kegunaan dari materi ekosistem yang dipelajari. setelah diterapkan model pembelajaran think pair share terhadap minat belajar. Siswa sudah ada kesadaran akan tujuan dan kegunaan mata pelajaran yang diperolehnya. Bila siswa perhatian kepada pelajaran ekosistem, maka pelajaran yang diterimanya akan dihayati, diolah di dalam pikirannya, sehingga timbul pengertian.
Pada kelas eksperimen dengan indikator perhatian tercermin dalam sintak model think pair share sebagai berikut:

a. Tahap berpikir

Pada tahap berpikir, siswa menceritakan semua temuan saat diminta untuk melihat sebuah gambar tentang kebakaran hutan. Peneliti juga memberikan cerita nyata tentang akibat dari kerusakan lingkungan. Setelah selesai menceritakan, siswa sadar akan tujuan dan kegunaan dalam mempelajari materi ekosistem. Siswa menunjukkan perhatiannya saat dalam tahap berpikir ketika diminta untuk menceritakan sebuah gambar dan memberikan suatu pertanyaan terkait dengan gambar yang diceritakannya tersebut. Pembelajaran dengan menggunakan gambar-gambar akan merangsang siswa untuk berpikir.

b. Tahap berbagi jawaban hasil diskusi

Pada tahap berbagi jawaban hasil diskusi, siswa secara bergiliran maju ke depan kelas untuk menceritakan hasil diskusinya. Setiap pasangan kelompok memerhatikan kelompok yang maju ke depan kelas. Masingmasing pasangan kelompok telah mengetahui kegunaan apa saja yang diperoleh setelah pembelajaran selesai. Kemudian peneliti juga memberikan beberapa manfaat dan hasil dari belajar ekosistem.

Pada kelas kontrol menggunakan metode ceramah, suasana pembelajaran di kelas kontrol terlihat pasif saat siswa diminta untuk menceritakan gambaran ekosistem kebakaran hutan.

d) Partisipasi

Berdasarkan lampiran 13, diketahui bahwa hasil skala minat belajar siswa dengan indikator partisipasi yaitu pada kelas eksperimen memiliki pencapaian $84,76 \%$ dengan kategori sangat tinggi, sedangkan pada kelas kontrol memiliki pencapaian $78,95 \%$ dengan 
kategori tinggi. Hal ini selaras dengan penelitian yang telah dilakukan Evi (2014), berdasarkan hasil penelitiannya bahwa hasil skala minat belajar siswa indikator perhatian adalah cukup baik dengan rata-rata jawaban sebesar 3,95. Tahap partisipasi ini, peneliti memberi kebebasan pada siswa. Siswa dalam mengikuti pembelajaran telah dapat menyelidiki sendiri, mengamati sendiri, belajar sendiri, mencari pemecahan masalah sendiri, dapat menjalankan perintah dan melaksanakan tugas setelah diterapkan model pembelajaran think pair share terhadap minat belajar.

Pada kelas eksperimen dengan indikator perhatian tercermin dalam sintak model think pair share sebagai berikut:

a. Tahap berpikir

Pada tahap berpikir, masingmasing siswa mengamati sendiri sebuah gambar tentang sebidang sawah, simbiosis dan kebakaran hutan. Setelah selesai mengamati, siswa diminta untuk menceritakan tentang gambar tersebut dan memberikan suatu pertanyaan terakit materi ekosistem yang dipelajari bersama. Siswa menunjukkan partipasinya saat diminta untuk bekerja sendiri dalam menceritakan sebuah gambar dan memberikan suatu pertanyaan terkait dengan gambar yang diceritakannya tersebut.

b. Tahap berpasangan

Pada tahap berpasangan, masing-masing siswa diminta untuk membentuk kelompok yang berjumlah dua orang. Setiap siswa memiliki pasangan kelompok dalam aktivitas belajar untuk bekerja sama saat mengamati komponen biotik dan komponen abiotik, mencari permasalahan kotak kosong jaring-jaring makanan. Siswa diberi kemudahan dalam belajar karena siswa tidak bekerja sendiri-sendiri melainkan saling bekerja sama satu sama lain sehingga hasil belajar yang diperoleh akan lebih baik.

c. Tahap berbagi jawaban hasil diskusi

Pada tahap berbagi jawaban hasil diskusi, siswa secara ikut berpastisipasi dalam menyampaikan hasil diskusi nya di depan kelas. Siswa juga memberikan kesimpulan dari hasil akhir pembelajaran.

Pada kelas kontrol menggunakan metode ceramah, suasana pembelajaran di kelas kontrol terlihat pasif karena partisipasi siswa masih belum tercipta saat proses pembelajaran berlangsung.

Pada kelas eksperimen indikator minat belajar terlihat pada proses pembelajaran menggunkan model think pair share yaitu mulai dari tahap think, pair dan share. Pada indikator minat belajar terlihat dari proses pembelajaran dari awal sampai akhir pembelajaran, dikarenakan pada tahap think, pair dan share siswa dituntut untuk memikirkan atau mengajukan suatu pertanyaan, bekerja sama satu sama lain dengan pasangan kelompok dan berbagi hasil jawaban di depan pasangan kelompok yang lain. memilih subtopik untuk kelompok masing-masing dan melaksanakan investigasi terhadap subtopik yang telah kelompok dapatkan sebelumnya. Melaksanakan, menyiapkan, dan mempresentasikan hasil diskusi kelompok membuktikan bahwa setiap kelompok berusaha belajar lebih baik lagi sehingga minat belajar siswa lamakelamaan akan bertambah dan hasil belajar yang diperoleh akan menjadi maksimal.

Dari keempat indikator minat belajar siswa, diketahui bahwa model think pair share terhadap minat menunjukkan nilai pencapaian minat belajar sangat tinggi. Melalui model think pair share, siswa dilibatkan bekerja sendiri, menyelidiki sendiri, mencari permasalahan sendiri dan melaksanakan tugas secara mandiri, sehingga pembelajaran tidak hanya berpusat pada guru saja karena guru sebagai fasilitator bagi siswa. Model think pair share dapat mengembangkan kemampuan siswa untuk berpikir sendiri 
mengenai suatu pertanyaan dan jawaban, berpasangan dan mendiskusikan mengenai apa yang telah dipikirkan, berbagi atau bekerja sama dengan kelas secara keseluruhan mengenai apa yang telah mereka bicarakan (Kunandar, 2011).

\section{KESIMPULAN}

Berdasarkan hasil penelitian yang dilakukan mengenai pengaruh penerapan model TPS (Think Pair Share) terhadap minat belajar siswa kelas VII di MTsN 1 Palembang, maka dapat di ambil kesimpulan sebagai berikut :

1. Nilai $t_{\text {hitung }} 2,922>t_{\text {tabel }} 1,667$ maka $\mathrm{H}_{\mathrm{a}}$ diterima dan $\mathrm{H}_{0}$ ditolak.

2. Berdasarkan skor rata-rata minat belajar siswa bahwa untuk skor kelas eksperimen yaitu sebesar 80,78 dan kelas kontrol sebesar 75,88 .

\section{DAFTAR PUSTAKA}

[1] Arikunto, S. 2007. Dasar-Dasar Evaluasi Pendidikan. Jakarta: Bumi Aksara.

[2] Azwar, S. 2015. Penyusunan Skala Psikologi. Yogyakarta: Pustaka Belajar.

[3] Hasbullah. 2012. Dasar-Dasar Ilmu Pendidikan (Umum dan Agama Islam). Jakarta: Rajawali Pers.

[4] Lin-Siegler. Ahn, J. Chen, J. 2016. Effects of Learning About Great Scientists Struggles on High School Students' Motivation to Learn Science. Journal of Educational Psychology. Advance online publication. doi: 10.1037/a0026224. 7 november 2011. Diakses 28 September 2016.

[5] Ismail, F. 2014. Evaluasi Pendidikan. Palembang: Tunas Gemilang.

[6] Kadir, A.A. F. Endri, Y. Baehaqi. Rido, K. Rosmiati dan Ahmad, N.. 2012. Dasar-Dasar Pendidikan. Jakarta: Kencana.
[7] Khodijah, N. 2016. Psikologi Pendidikan. Jakarta: Rajawali Press.

[8] Mardodo, Budiyono, dan Sujadi.I. 2014. Implementasi Pembelajaran Kooperatif Model Think Pair Share dan Learning Together dengan Pendekatan Pembelajaran Matematika Realistik ditinjau dari Minat Belajar Siswa. Jurnal Elektronik Pembelajaran Matematika. ISSN: 2339-1685 Vol.2 (5) Hal 513-524 Juli 2014.

Dalam http://jurnal.fkip.uns.ac.id/index.php/s 2math/article/download/4376/3061. Diakses 28 September 2016.

[9] Matin. 2013. Dasar-dasar Perencanaan Pendidikan. Jakarta: Rajawali Pers.

[10] Slameto, 2015. Belajar dan FaktorFaktor yang Mempengaruhi. Jakarta: Rineka Cipta

[11] Sudijono, A. 2008. Pengantar Statistik Pendidikan. Jakarta: Raja Grafindo Persada.

[12] Sugiyono. 2015. Metode Penelitian Pendidikan (Pendekatan Kuantitatif, Kualitatif, dan R\&D). Bandung: Alfabeta.

[13] Sukardi, I. 2013. Model-Model Pembelajaran Modern Bekal untuk Guru Profesional. Palembang: Tunas Gemilang Press.

[14] Wahab, R. 2015. Psikologi Belajar. Jakarta: Rajawali Press. 